\title{
Verification of the ERA-Interim Reanalysis Data in the Azov-Black Sea Basin
}

\author{
T. B. Grankina ${ }^{1, *}$, R. A. Ibrayev ${ }^{1,2,3}$, P. A. Mogilnikov ${ }^{3}$ \\ ${ }^{1}$ Shirshov Institute of Oceanology, Russian Academy of Sciences, Moscow, Russian Federation \\ ${ }^{2}$ Marchuk Institute of Numerical Mathematics, Russian Academy of Sciences, Moscow, Russian Federation \\ ${ }^{3}$ Moscow Institute of Physics and Technology (National Research University), \\ Dolgoprudny, Russian Federation \\ *grankina@gmail.com
}

Purpose. The paper purpose is to assess quality of meteorological information for the Azov-Black Sea basin derived from the ERA-Interim reanalysis (the European Centre for Medium-Range Weather Forecasts), and to examine possibility of using the obtained data for presetting atmospheric forcing in the numerical hydrodynamic model of the Black and Azov seas. ERA-Interim

Methods. The analysis is based on comparison of the annual average fields with the measurement data on the atmospheric circulation parameters represented in hydrometeorological atlases. The most significant discrepancies between the ERA-Interim fields and the data of climatic arrays are noted and, consequently, the discrepancy-related potential errors arising in reproducing water circulation in the indicated seas are considered.

Results and Conclusions. The comparative analysis showed that, for a number of the parameters, the reanalysis data were in qualitative agreement with the measurements. The highest discrepancies (up to 70\%) were revealed in the precipitation field nearby the Caucasian coast in autumn. Such an error in the boundary conditions can negatively affect both the sea surface salinity distribution in the numerical modeling and, therefore, reproduction of thermohaline circulation in this region of the sea. A significant error in the results of numerical modeling can also be induced by the discrepancies in the wind fields. In the ERA-Interim data, the wind speed module is generally understated by $7 \%$ over the whole Black Sea in a spring-summer period, and by $20-25 \%$ in the Azov Sea throughout a year. The direction of the resultant wind is the most distorted in summer, whereas in winter, the deviations are significant only in the southeastern part of the Black Sea. The best agreement is observed between the temperature and air humidity fields, and the climatic arrays' data: the discrepancies between the values of these parameters are minimal.

Keywords: the Black Sea, the Azov Sea, ERA-Interim, hydrodynamic modeling, atmospheric forcing.

Acknowledgement: the research is carried out in the Shirshov Institute of Oceanology, RAS within the framework of the state order of FASO, RAS (theme No. 0149-2018-0021) under the partial support of RFBR (project No. 17-05-01282).

For citation: Grankina, T.B., Ibrayev, R.A. and Mogilnikov, P.A., 2019. Verification of the ERAInterim Reanalysis Data in the Azov-Black Sea Basin. Physical Oceanography, [e-journal] 26(3), pp. 236-246. doi:10.22449/1573-160X-2019-3-236-246

DOI: $10.22449 / 1573-160 X-2019-3-236-246$

(C) 2019, T. B. Grankina, R. A. Ibrayev, P. A. Mogilnikov

(C) 2019, Physical Oceanography

\section{Introduction}

Numerical modeling has been used to study the general structure and variability of the Black Sea circulation for many years [1-11]. Carrying out numerical experiments requires setting the correct boundary conditions at the sea surface. For this purpose the joint sea-atmosphere model is applied, which is associated with a number of difficulties, in particular with the need to maintain a balance of flows at the boundary of two media. There is another way to adjust the 236

PHYSICAL OCEANOGRAPHY VOL. 26 ISS. 3 (2019) 
model of the sea circulation separately. It is to set the parameters of the atmosphere and the currents on the sea surface based on data from various reanalyzes of the atmospheric circulation.

One of the most modern reanalyzes is the ERA-Interim Reanalysis of the European Center for Medium-Range Weather Forecasts (ECMWF) [12], which is widely used in studies of various seas, including the Azov and Black Seas [11, $13,14]$. The spatial resolution of these data is $0.75^{\circ}$ (about $80 \mathrm{~km}$ ), the time step is 6 hours. The data cover the period from 1979 to the present day. It should be borne in mind that ERA-Interim is a reanalysis of the global atmospheric circulation, so in each separate region of the planet it may contain errors typical for it $[15,16]$. For example, when constructing fields along the coast of the AzovBlack Sea basin, errors may occur due to the inability to take into account the exact contours of the coastline. Such parameters as air temperature and thermal radiation have contrasting values over the sea and over land. Thus, when using ERA-Interim data in the considered region, their verification is necessary.

For this purpose, according to the ERA-Interim data, the average long-term mean monthly and mean annual fields of temperature and humidity, module of wind speed, resulting wind, atmospheric pressure, precipitation, solar and thermal radiation were constructed. These particular parameters and flows are used to define the external effect on the surface in the numerical model of hydro- and thermodynamics of the ocean that was developed in the study [17].

To obtain the average climate values, the ERA-Interim data were averaged over a 30-year period - from 1979 to 2008. The obtained distributions of these functions are compared with climatic fields represented in hydrometeorological atlases of the Black and Azov seas [18-20]. It should be noted that these hydrometeorological atlases contain information on the average state of the atmosphere for earlier periods, partially or not at all intersecting with the period in question. This does not give possibility to fully judge the ERA-Interim data quality, since the discrepancies found may be due both to errors in the reanalysis data and hydrometeorological atlases themselves and to climate variations. However, the present study will proceed from the assumption that any climatic changes in this region in the second half of the $20^{\text {th }}$ - the beginning of the $21^{\mathrm{st}}$ centuries were not cardinal and data for different periods is comparable.

When conducting a comparative analysis, emphasis was placed on the values of the considered fields in the open parts of the sea, because due to the low spatial resolution of the ERA-Interim data, the coastline in them is taken into account roughly, which will inevitably lead to a distortion of the atmospheric parameters along the coasts. Therefore, the data quality will be estimated by their relevance to climatic fields in the open sea, the territory of which accounts for the majority of the area of the studied basin.

On the basis of such a comparative analysis, a conclusion is drawn about the ERA-Interim reanalysis applicability as a source of data on external effects in simulation of the Azov and Black Sea circulation in a numerical model and also discusses the main discrepancies with atlases and possible associated modeling errors. 


\section{Air Temperature}

In Fig. 1 shows the average monthly fields of air temperature according to the ERA-Interim data for the central months of four seasons. A comparative analysis showed that the ERA-Interim fields are in good agreement with the atlas data for the Black [18] and Azov [19] seas in all seasons in the greater part of the Azov-Black Sea basin. The average annual temperature distribution in the entire basin almost coincides with the data of climatic arrays. The greatest deviation of the ERA-Interim data relative to the field measurement data is observed on the southeast Black Sea coast from February to June with a slight underestimation of air temperature by $0.5-1{ }^{\circ} \mathrm{C}$. This may be due to the use of observational data in the construction of climatic fields [18], most of which were carried out in the daytime. Above the Azov Sea, the temperature according to reanalysis is overestimated by an average of $1^{\circ} \mathrm{C}$, which, during model calculations, may affect the time of onset and the speed of ice cover formation in the autumn-winter period.
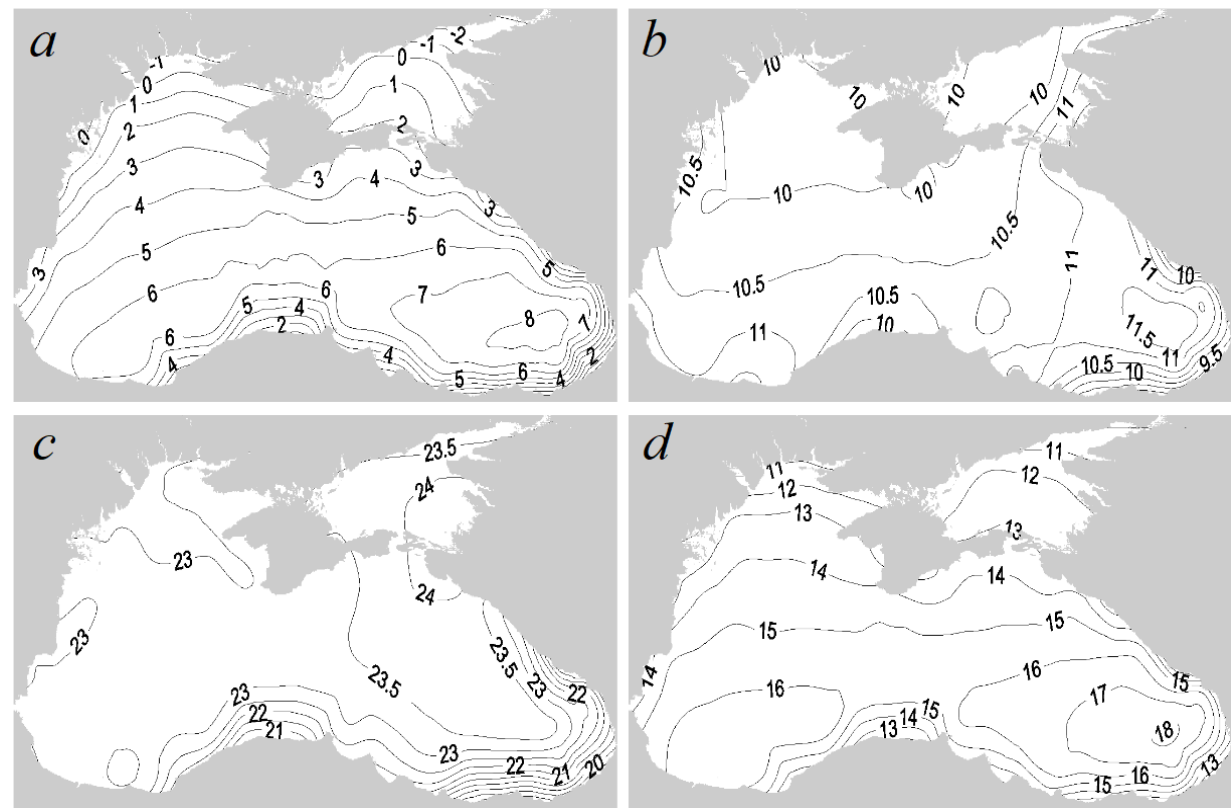

F i g. 1. Average long-term distribution of air temperature at the $2 \mathrm{~m}$ height $\left({ }^{\circ} \mathrm{C}\right)$ based on the ERAInterim data for 1979-2008 in January $(a)$, April $(b)$, July $(c)$ and October $(d)$

The average air temperature over the open sea is generally higher than that of the coast, and only in the spring the temperature distribution is reversed. The maximum average monthly air temperature falls in July-August (about $24{ }^{\circ} \mathrm{C}$ ). The minimum is in January - February $\left(-1^{\circ} \mathrm{C}\right)$. The average annual air temperature over the sea varies from $10{ }^{\circ} \mathrm{C}$ in the north to $15{ }^{\circ} \mathrm{C}$ in the southeast, which is in good agreement with the data [20]. In the cold season, its characteristic meridional increase is clearly visible. In summer, the temperature field is more uniform. 


\section{Air Humidity}

To carry out a comparative analysis of the humidity fields, according to the ERA-Interim data, the multi-year average monthly distributions of the partial water vapor pressure were calculated (Fig. 2). According to observations, the intraannual changes in air humidity are similar to the annual course of air temperature. In the cold season, the average annual spatial distribution of the partial water vapor pressure over the sea is similar to the temperature distribution. The corresponding identity of the humidity and temperature fields in the winter months is observed in the ERA-Interim data. Comparison of the data obtained with the data of hydrometeorological atlases also revealed that the ERA-Interim data corresponded to climatic data: only minor deviations were observed (up to $0.5 \mathrm{hPa}$ ). According to the ERA-Interim and climate data, the lowest values of water vapor pressure are observed in January-February (5-9 $\mathrm{hPa}$ ), the maximum in August (19-24 hPa). The average annual humidity values throughout the AzovBlack Sea basin are 10-14.5 hPa.
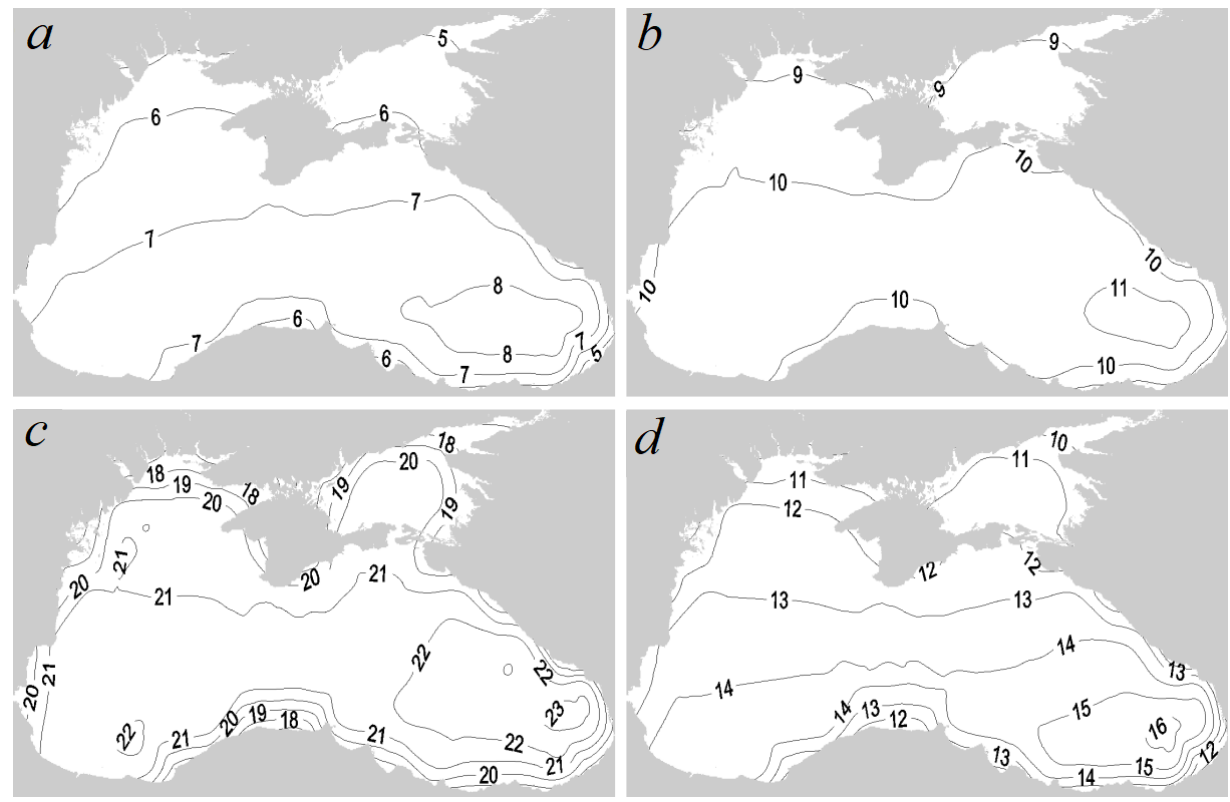

F i g. 2. Average long-term distribution of water vapor partial pressure at the $2 \mathrm{~m}$ height $\left({ }^{\circ} \mathrm{C}\right)$ based on the ERA-Interim data for 1979-2008 in January $(a)$, April (b), July $(c)$ and October $(d)$

\section{Wind Speed}

Wind is the most important factor in the water circulation formation in the entire World Ocean, including the Black and Azov Seas. This section discusses the average module of speed and the resultant wind at a height of $10 \mathrm{~m}$ (Fig. 3).

According to ERA-Interim, throughout the year the wind speed over the Black Sea increases from southeast to northwest. It somewhat contradicts climate data presented in the hydrometeorological atlas [18], according to which the wind speed has a predominantly meridional distribution with increasing south to north. In this case, the differences in the values of the wind speed module are relatively small. 
In the autumn-winter period, the wind speed fields according to the ERA-Interim data are in good agreement with climate data in the majority of the Black Sea area. The only exception is the southwestern part, where at this time the wind speed is $1-1.5 \mathrm{~m} / \mathrm{s}$ overestimated compared with the data of climatic arrays. The same overestimation is observed in some spring months, however, in the spring-summer period in most of the Black Sea, wind speed according to ERA-Interim, on the contrary, is underestimated by $0.5-1 \mathrm{~m} / \mathrm{s}$, most significantly in the north-west.

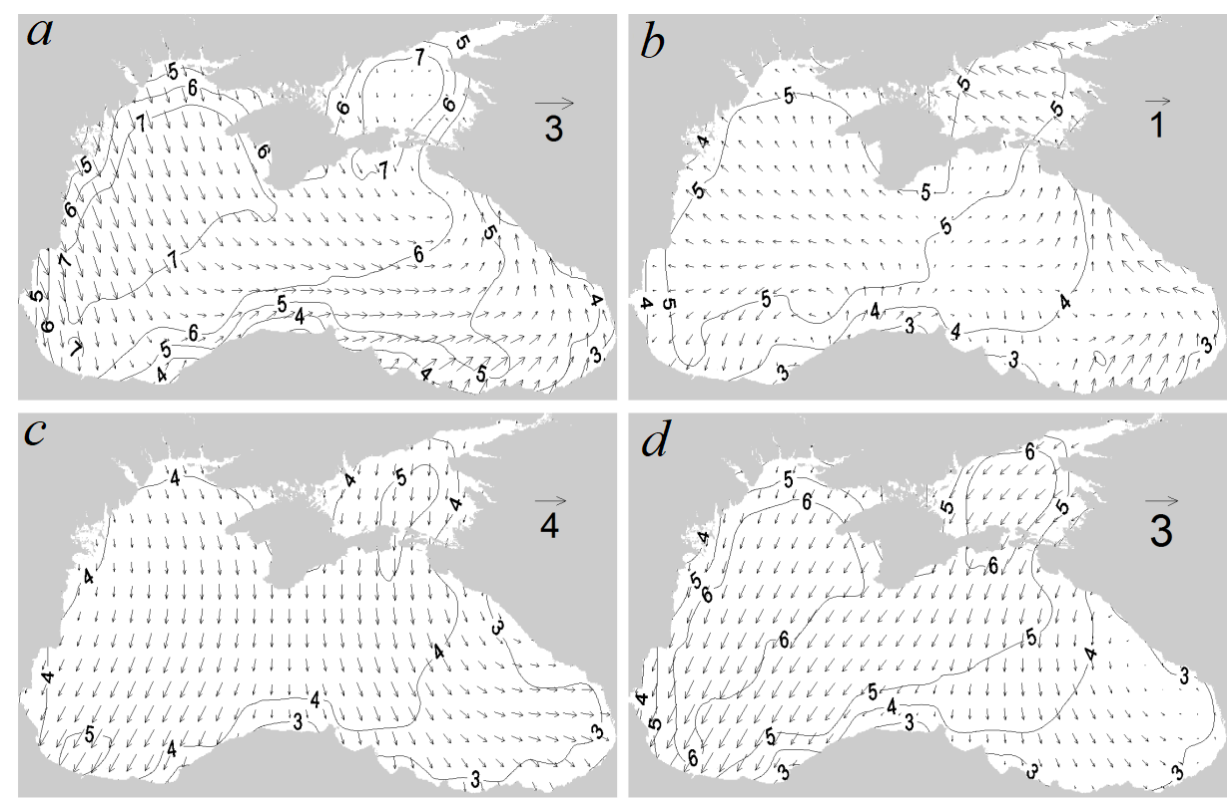

F i g. 3. Average long-term distribution $(\mathrm{m} / \mathrm{s})$ of the resultant wind (vectors) and the wind speed mean module (isolines) based on the ERA-Interim data for 1979-2008 in January (a), April (b), July $(c)$ and October $(d)$

In the Azov Sea, the deviation of average wind speeds according to ERAInterim data is more significant. In general, as in the Black Sea, the deviation is minimal in the autumn-winter period. It is most pronounced in spring, when wind speed in most of the Azov basin is underestimated relative to climatic data [19] by an average of $2 \mathrm{~m} / \mathrm{s}$, in summer and autumn - by $1-1.5 \mathrm{~m} / \mathrm{s}$. During the winter period, a significant discrepancy with the data of climatic arrays is observed only in the Taganrog Bay: here the speeds are underestimated by about $1 \mathrm{~m} / \mathrm{s}$. This situation is observed throughout the year. At the same time, the wind speed distribution qualitatively corresponds to the climatic data: its maximum speeds are noted in the central part of the Azov Sea, the minimum ones - along the coast and in the Taganrog Bay.

The resultant wind field (compared to wind speed) based on the ERA-Interim data shows a much greater inconsistency with the data of climatic arrays. First of all, this refers to the summer period, when the northern winds prevail over the greater part of the Azov-Black Sea basin, while according to climatic data [18], 
the wind in this season has mainly western (south-western or north-western) directions [18]. In the cold season, the wind direction according to the ERAInterim data is generally consistent with the climatic data, with the exception of the southeastern part of the Black Sea, where, due to the formation of high pressure areas above the Armenian highland, eastern winds predominate. According to the reanalysis, in this region the wind direction changes to the south, that is, the influence of this high pressure area is less pronounced than in the climatic field of the wind. In general, as a result of these discrepancies in the determination of the prevailing wind directions, especially in the summer, there may be significant errors in the simulation of currents in the considered basin.

\section{Atmospheric Pressure}

In the ocean modeling hydro- and thermodynamics problems, atmospheric pressure is the secondary factor. Directly this parameter is used only to calculate evaporation from the sea surface. Therefore, possible errors will have only a minor effect on the simulation results in comparison with errors in other components of atmospheric effects. There is no need to dwell on this feature. The maximum monthly average pressure, according to observational data, is monitored on the northern, northeastern coasts in November, on the southern, south-western coast in January and is $1019-1021 \mathrm{hPa}$. According to ERA-Interim, the maximum value $(1020 \mathrm{hPa})$ is observed only in January on the southern and southwestern coasts. The deviation of the average monthly values of atmospheric pressure, according to ERA-Interim, averages about $0.5 \mathrm{hPa}$ in the direction of over-data in February, April, August and October. In November, on the contrary, the data is slightly underestimated. The minimum $(1015.5 \mathrm{hPa})$ and maximum $(1017.5 \mathrm{hPa})$ values per year according to the atlas and according to the ERA-Interim (1015.9 and $1016.8 \mathrm{hPa}$, respectively) are in good agreement, despite the significant disparity of wind fields.

\section{Precipitation}

Direct measurements of precipitation are systematically carried out mainly on the coast, therefore the picture presented in hydrometeorological atlases cannot be considered as a reference when compared with reanalysis data (Fig. 4). The main deviations of the ERA-Interim data from the data of climatic arrays are considered below.

As expected, the discrepancy between the reanalysis data and the hydrometeorological atlases $[18,19]$ is large, although the picture of precipitation distribution is qualitatively the same. The greatest deviations of the reanalysis data from the climatic one are observed in the autumn months near the coast of Batumi: the intensity of precipitation here is more than doubled to $170 \mathrm{~mm} / \mathrm{month}$. When numerically reproducing the thermohaline circulation of Black Sea waters, such a significant error will inevitably lead to overestimations of the upper layer salinity and, probably, excessively intensive water convection. In winter, according to ERA-Interim, in this part of the Black Sea, there is also an underestimation of precipitation intensity, but more moderate - up to $20 \mathrm{~mm} / \mathrm{month}$. In spring and 
summer, the values are close to climate data. In the rest of the Black Sea, discrepancies between the ERA-Interim reanalysis data and observational data are less significant and are about $20 \mathrm{~mm} /$ month in one direction or another.

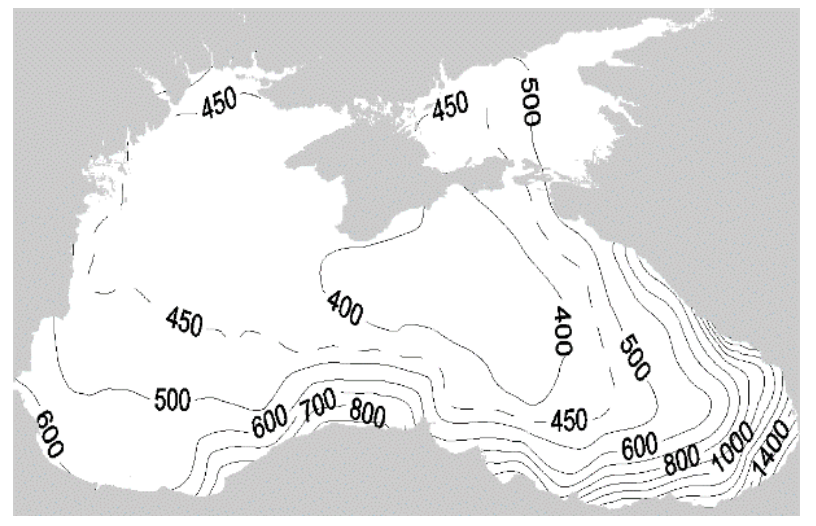

F i g. 4. Average long-term distribution of precipitation ( $\mathrm{mm} /$ year) based on the ERA-Interim data for $1979-2008$

In the Azov Sea throughout the year, according to reanalysis, precipitation intensity exceeds climate data by $5-10 \mathrm{~mm} / \mathrm{month}$. On average, the year the greatest deviation from climate data is observed in the southeastern part of the sea (an understatement of about $500 \mathrm{~mm} /$ year). A significant deviation (an excess of about $200 \mathrm{~mm}$ /year) of average annual precipitation intensity is also observed in the north-west of the region.

\section{Radiation Flows}

Solar and thermal radiation substantially depend on local cloud conditions, which are considered in climate atlases very approximately. Therefore, the deviations of these fields, as well as the precipitation fields, according to the ERAInterim data from the average climatic values should not be unambiguously interpreted as an error. However, it was shown in [21] that reanalysis data often indicate a clear sky when it is actually cloudy. The authors of this paper caution against direct use of ERA-Interim data on solar radiation without proper adjustments.

Fig. 5 shows the average annual perennial fields of ERA-Interim solar and thermal radiation. According to the hydrometeorological atlas of the Black Sea [18], the absorbed solar radiation has a strictly meridional distribution with an increase in flux from $4500 \mathrm{MJ} /\left(\mathrm{m}^{2} \mathrm{~g}\right)$ in the north to $4900 \mathrm{MJ} /\left(\mathrm{m}^{2} \mathrm{~g}\right)$ in the south. In the ERA-Interim reanalysis, the incoming solar radiation distribution has a much more complex structure and values exceeding those indicated by $800-900 \mathrm{MJ} /\left(\mathrm{m}^{2}\right.$ year $)$. If the albedo of the sea surface is considered about $10 \%$ (in areas of the sea with no winter ice cover), it can concluded that the ERAInterim data exceed climatic data by an average of about $6 \%$. The same relative overestimation was also noted in the Azov Sea water area (according to [19]). Nevertheless, it should be noted that the reanalysis data at the coast of 
the Caucasus have a local minimum due to increased cloudiness, while this minimum is practically not traced in the atlas data. Thus, ERA-Interim data may be more correct than climate atlases, at least in certain areas of the studied basin.

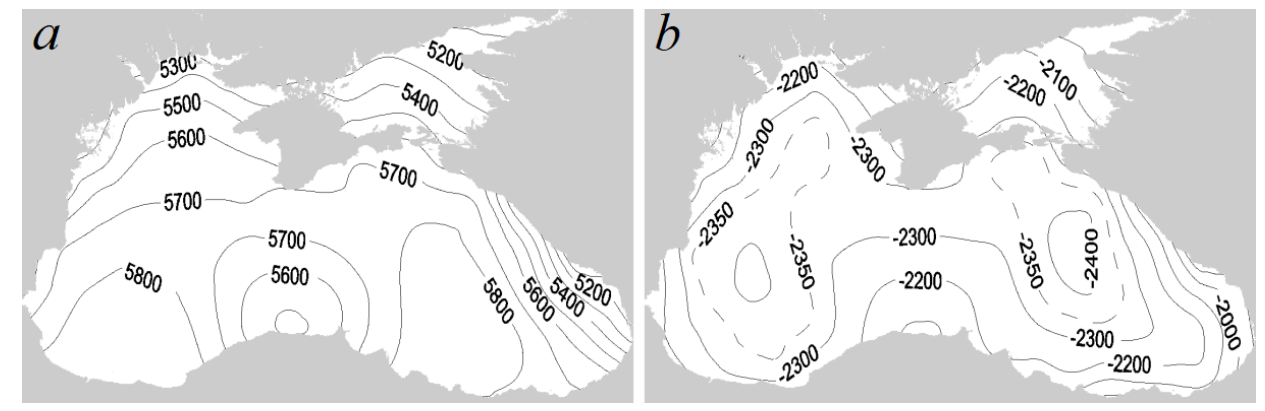

F i g. 5. Average long-term distribution of the arriving solar radiation $(a)$ and the effective thermal radiation $(b)$ on the surface $\left(\mathrm{MJ} /\left(\mathrm{m}^{2}\right.\right.$ year $\left.)\right)$ based on the ERA-Interim data for 1979-2008

In the field of effective thermal radiation, there are significantly greater discrepancies with climate data. In the Black Sea, its intensity is higher than the values calculated in the climatic array [18], by $5 \%$ in the southeastern and northwestern parts of the sea, by $10 \%$ in the northeast, by $10-15 \%$ in the central part and up to $25-30 \%$ in the southwest. Probably, the reason for this discrepancy is an underestimation of the average cloudiness during the reanalysis, which can also cause excessive solar radiation. Moreover, an increased solar radiation flow will inevitably lead to thermal over-inflation, since the latter directly depends on the sea surface temperature. Thus, the adjustment of both radiation flows must be made consistent.

In the Azov Sea, the average annual thermal radiation exceeds climatic data [19] by 30-40\%, and its annual variation correlates with the sea surface temperature, while according to the climate atlas, its minimum should occur in the summer period, and the maximum - in the winter. Considering that in winter, the Azov Sea is partially or completely covered with ice, which shields heat flows on the surface, such an annual course in the atlas data seems doubtful, and the need to correct the ERA-Interim data on thermal radiation in the Azov Sea is not obvious.

\section{Conclusion}

A comparative analysis showed that the ERA-Interim reanalysis data is generally consistent with the climate atlases of the Black and Azov Seas. The fields of air temperature and partial vapor pressure in the subsurface layer have minimal differences with climatic data (within $1{ }^{\circ} \mathrm{C}$ and $0.5 \mathrm{hPa}$, respectively) and do not require significant adjustment. Atmospheric pressure is also close to the data of hydrometeorological atlases. The most significant inconsistencies in climatic conditions are noted in the field of the resultant wind, primarily in the summer period, when it has mainly northern directions instead of western ones. Wind speed also has the largest discrepancies with climate data in summer, but in absolute value they are relatively small: up to $1-1.5 \mathrm{~m} / \mathrm{s}$ in the Black Sea and up to $2 \mathrm{~m} / \mathrm{s}$ in the Azov Sea. The precipitation intensity according to the ERA-Interim data 
qualitatively corresponds to the data of climatic arrays, with the exception of the southeastern part of the Black Sea in the autumn period, where it is underestimated by $170 \mathrm{~mm} / \mathrm{month}$, that is, more than twice. So it can significantly affect the salinity of the upper sea layer when carrying out numerical calculations of its circulation. In our opinion radiation flows, in the ERA-Interim data have more correct spatial-temporal variability relative to the fields presented in hydrometeorological atlases, but in absolute value, they are systematically overestimated. The intensity of solar radiation in both the Black and the Azov Sea exceeds average climatic values by an average of $6 \%$ annually. The intensity of effective thermal radiation is higher than climate data in various regions of the Black Sea by 5-30 \% and in the Azov Sea - by 30-40\%. Presumably, the reason for the overestimation of both solar and thermal radiation is the same underestimated average cloudiness in the reanalysis. Also, when calculating reanalysis fields, an excessive inflow of solar radiation can lead to an overestimation of thermal radiation due to overheating of the sea surface. Therefore, the adjustment of the two radiation flows should be carried out in concert.

In general, the ERA-Interim reanalysis data can be used as atmospheric forcing when modeling the thermohaline circulation in the Azov-Black Sea basin. However, if they are not corrected, very significant errors in the reproduction and dynamics of the waters and their thermohaline structure should be expected. Although the correction of precipitation fields and radiation flows can be done quite simply, the elimination of errors in the wind field (first of all, wind direction) is a very nontrivial task. The method of dynamic regionalization of reanalysis data is considered one of the most promising ways to solve this problem [22].

\section{REFERENCES}

1. Knysh, V.V, Korotaev, G.K. and Lishaev, P.N., 2016. Methodology of Application of the Black Sea Three-Dimensional Temperature and Salinity Fields Reconstructed on the Basis of Altimetry and Scanty Measurements in the Operational Prognostic Model. Physical Oceanography, [e-journal] (2), pp. 46-61. doi:10.22449/1573-160X-2016-2-46-61

2. Demyshev, S.G. and Dymova, O.A., 2017. Calculation and Analysis of Water Circulation Energetics in the Black Sea Coastal Regions. Physical Oceanography, [e-journal] (3), pp. 4557. doi:10.22449/1573-160X-2017-3-45-57

3. Dianskii, N.A., Fomin, V.V., Zhokhova, N.V. and Korshenko, A.N., 2013. Simulations of Currents and Pollution Transport in the Coastal Waters of Big Sochi. Izvestiya, Atmospheric and Oceanic Physics, [e-journal] 49 (6), pp. 611-621. doi:10.1134/S0001433813060042

4. Stanev, E.V., 1990. On the Mechanisms of the Black Sea Circulation. Earth-Science Reviews, [e-journal] 28(4), pp. 285-319. https://doi.org/10.1016/0012-8252(90)90052-W

5. Stanev, E.V., Bowman, M.J., Peneva, E.L. and Staneva, J.V., 2003. Control of Black Sea Intermediate Water Mass Formation by Dynamics and Topography: Comparison of Numerical Simulations, Surveys and Satellite Data. Journal of Marine Research, [e-journal] 61(1), pp. 59-99. https://doi.org/10.1357/002224003321586417

6. Miladinova, S., Stips, A., Garcia-Gorriz, E. and Macias Moy, D., 2017. Black Sea Thermohaline Properties: Long-Term Trends and Variations. Journal of Geophysical Research: Oceans, [e-journal] 122(7), pp. 5624-5644. https://doi.org/10.1002/2016JC012644 
7. Miladinova, S., Stips, A., Garcia-Gorriz, E. and Macias Moy, D., 2018. Formation and Changes of the Black Sea Cold Intermediate Layer. Progress in Oceanography, [e-journal] 167, pp. 11-23. https://doi.org/10.1016/j.pocean.2018.07.002

8. Kubryakov, A.A. and Stanichny, S.V., 2015. Seasonal and Interannual Variability of the Black Sea Eddies and its Dependence on Characteristics of the Large-Scale Circulation. Deep-Sea Research I: Oceanographic Research Papers, [e-journal] 97, pp. 80-91. http://dx.doi.org/10.1016/j.dsr.2014.12.002

9. Korotenko, K.A., 2015. Modeling Mesoscale Circulation of the Black Sea. Oceanology, [e-journal] 55(6), pp. 820-826. https://doi.org/10.1134/S0001437015060077

10. Beşiktepe, Ş., Lozano, C.J. and Robinson, A.R., 2001. On the Summer Mesoscale Variability of the Black Sea. Journal of Marine Research, [e-journal] 59(4), pp. 475-515. https://doi.org/10.1357/002224001762842163

11. Lishaev, P.N., Korotaev, G.K., Knysh, V.V., Mizyuk, A.I. and Dymova, O.A., 2014. Vosstanovlenie Sinopticheskoy Izmenchivosti Gidrofizicheskikh Poley Chernogo Morya na Osnove Reanaliza za 1980-1993 Gody [Reproduction of Synoptic Variability of the Black Sea Hydrophysical Fields Based on Reanalysis for 1980-1993]. Morskoy Gidrofizicheskiy Zhurnal, (5), pp. 49-68 (in Russian).

12. Dee, D.P., Uppala, S.M., Simmons, A.J., Berrisford, P., Poli, P., Kobayashi, S., Andrae, U., Balmaseda, M.A., Balsamo, G. [et al.], 2011. The ERA-Interim Reanalysis: Configuration and Performance of the Data Assimilation System. Quarterly Journal of the Royal Meteorological Society, [e-journal] 137(656), pp. 553-597. https://doi.org/10.1002/qj.828

13. Sukhikh, L.I. and Dorofeyev, V.L., 2016. The Study of Sensitivity of the Black Sea Hydrophysical Fields Reanalysis Results to the Applied Atmospheric Forcing. Physical Oceanography, [e-journal] (5), pp. 45-60. doi:10.22449/1573-160X-2016-5-45-60

14. Efimov, V.V., Savchenko, A.O. and Anisimov, A.E., 2014. Osobennosti Teploobmena Chernogo Morya s Atmosferoy v Osenne-Zimniy Period [Features of the Black Sea Atmosphere Heat Exchange in Autumn-Winter Period]. Morskoy Gidrofizicheskiy Zhurnal, (6), pp. 71-81 (in Russian).

15. Berg, P., Feldmann, H. and Panitz, H.-J., 2012. Bias Correction of High Resolution Regional Climate Model Data. Journal of Hydrology, [e-journal] 448-449, pp. 80-92. https://doi.org/10.1016/j.jhydrol.2012.04.026

16. Cattiaux, J., Douville, H. and Peings, Y., 2013. European Temperatures in CMIP5: Origins of Present-Day Biases and Future Uncertainties. Climate Dynamics, [e-journal] 41(11-12), pp. 2889-2907. https://doi.org/10.1007/s00382-013-1731-y

17. Ibraev, R.A. and Dyakonov, G.S, 2016. Modeling of Ocean Dynamics with Large Variations in Sea Level. Izvestiya, Atmospheric and Oceanic Physics, [e-journal] 52(4), pp. 455-466. doi:10.1134/S000143381604006X

18. Altman, E.N. and Simonov, A.I. eds, 1991. Gidrometeorologiya i Gidrokhimiya Morey SSSR. T. IV. Chernoe More. Vyp. 1. Gidrometeorologicheskie Usloviya [Hydrometeorology and Hydrochemistry of the USSR Seas. Vol. IV. The Black Sea. Iss. 1. Hydrometeorologic Conditions]. Saint-Petersburg: Gidrometeoizdat, 428 p. (in Russian).

19. Goptarev, N.P., Simonov, A.I., Zatuchnaya, B.M. and Gershanovich, D.E., 1991. Gidrometeorologiya i Gidrokhimiya Morey SSSR. T. V. Azovskoe More. [Hydrometeorology and Hydrochemistry of the USSR Seas. Vol. V. The Azov Sea]. Saint-Petersburg: Gidrometeoizdat, 235 p. (in Russian).

20. Ilyin, Yu.P., Repetin, L.N., Belokopytov, V.N., Goryachkin, Yu., Dyakov, N.N., Kubryakov, A.A. and Stanichny, S., 2012. Gidrometeorologicheskie Usloviya Morey Ukrainy. T. 2: Chernoe More [Hydrometeorological Conditions of the Ukrainian Seas. Vol. 2. The Black Sea]. Sevastopol: ECOSI-Gidrofizika, 421 p. (in Russian).

21. Boilley, A. and Wald, L., 2015. Comparison between Meteorological Re-analyses from ERAInterim and MERRA and Measurements of Daily Solar Irradiation at Surface. Renewable Energy, [e-journal] 75, pp. 135-143. https://doi.org/10.1016/j.renene.2014.09.042 
22. Anisimov, A.E., Yarovaya, D.A. and Barabanov, V.S., 2015. Reanalysis of Atmospheric Circulation for the Black Sea-Caspian Region. Physical Oceanography, [e-journal] (4), pp. 13-25. doi: 10.22449/1573-160X-2015-4-13-25

About the authors:

Tatiana B. Grankina - Research Associate, Shirshov Institute of Oceanology, Russian Academy of Science (36 Nahimoskiy pr., Moscow, 117997, Russian Federation), Ph.D.,(Math-Phys.), grankina@gmail.com

Rashit A. Ibrayev - Chief Research Associate, Marchuk Institute of Numerical Mathematics, Russian Academy of Sciences (8 Gubkin St., Moscow, 119333, Russian Federation), Corresponding Member, Russian Academy of Sciences, Dr.Sci. (Phys.-Math.), ResearcherID: S-6750-2016, ibrayev@mail.ru

Pavel A. Mogilnikov - Bachelor of Applied Physics and Mathematics, Master's student, Moscow Institute of Physics and Technology (National Research University) (9 Institutskiy Lane, Dolgoprudny, Moscow Region, 141701, Russian Federation)

Contribution of the co-authors:

Tatiana B. Grankina - the problem study, research work, data processing and analysis of the results, the article text preparation

Rashit A. Ibrayev - scientific supervision, the scientific problem formulation, critical analysis of the results and the article text

Pavel A. Mogilnikov - computer processing of ERA-Interim reanalysis data arrays, preparation of the graphic material

All the authors have read and approved the final manuscript.

The authors declare that they have no conflict of interest. 